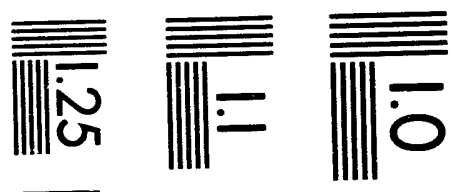

$$
\begin{aligned}
& \sqrt{\underline{\underline{\underline{\underline{n}}}}}
\end{aligned}
$$

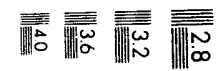

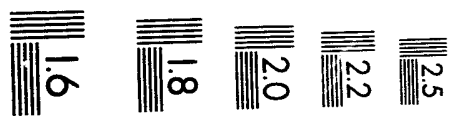



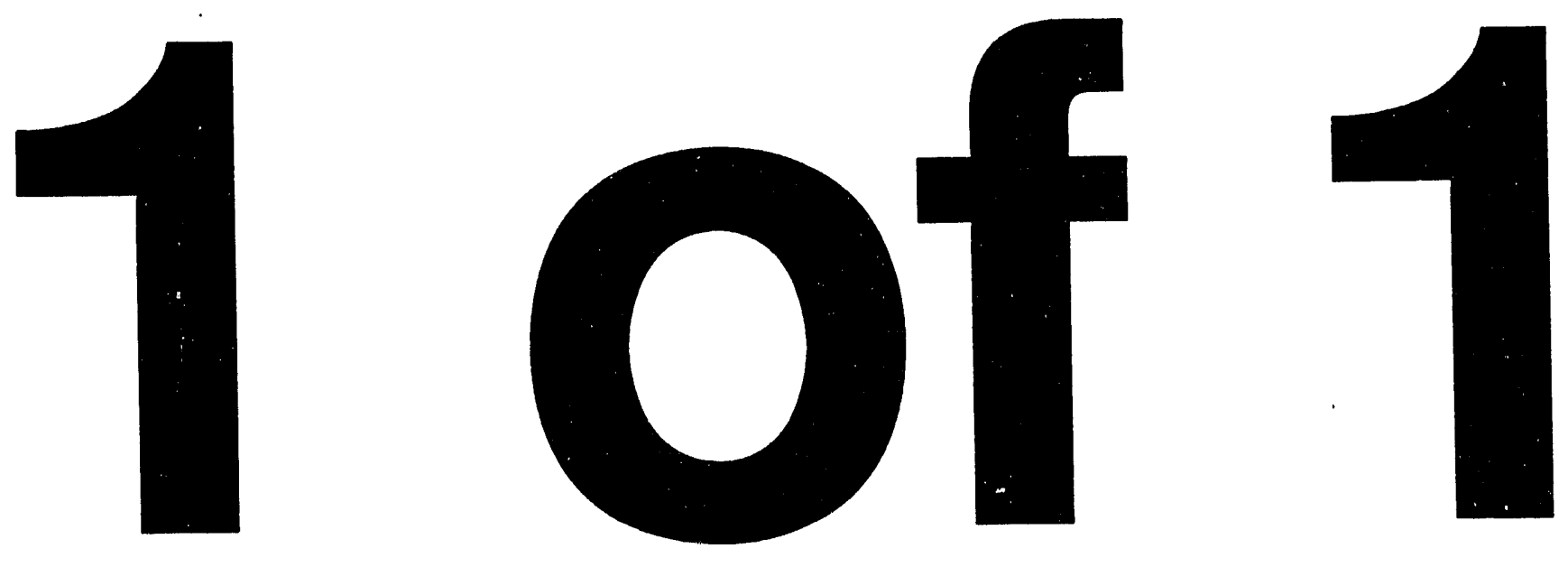


\title{
THE WIPP TRANSPORTATION SYSTEM: DEDICATED TO SAFETY
}

\author{
T. Ward \\ Westinghouse Electric Corporation \\ WIPP Project \\ P.0. Box 2078 \\ Carlsbad, NM 88221 \\ M. McFadden \\ U.S. Department of Energy \\ WIPP Project \\ P.0. Box 3090 \\ Carlsbad, NM 88221
}

\begin{abstract}
When developing a transportation system to transport transuranic (TRU) waste from ten widely-dispersed generator sites, the Department of Energy (DOE) recognized and addressed many challenges. Shipments of waste to the Waste Isolation Pilot Plant (WIPP) were to cover a twenty-five year period and utilize routes covering over twelve thousand miles in twenty-three states. Enhancing public safety by maximizing the payload, thus reducing the number of shipments, was the primary objective. To preclude the requirement for overweight permits, the DOE started with a total shipment weight limit of 80,000 pounds and developed an integrated transportation system consisting of a Type "B" package to transport the material, a lightweight tractor and trailer, stringent driver requirements, and a shipment tracking system referred to as "TRANSCOM."
\end{abstract}

\section{DISCLAIMER}

This report was prepared as an account of work sponsored by an agency of the United States Government. Neither the United States Government nor any agency thereof, nor any of their employees, makes any warranty, express or implied, or assumes any legal liability or responsibility for the accuracy, completeness, or usefulness of any information, apparatus, product, or process disclosed, or represents that its use would not infringe privately owned rights. Reference herein to any specific commercial product, process, or service by trade name, trademark, manufacturer, or otherwise does not necessarily constitute or imply its endorsement, recommendation, or favoring by the United States Government or any agency thereof. The views and opinions of authors expressed herein do not necessarily state or reflect those of the United States Government or any agency thereof.

Work supported by the U.S. Department of Energy Assistant Secretary for Defense Programs

Office of Defense Waste and Transportation Management, under DOE Contract No. DE-ACO4-86AL31950 


\section{INTRODUCTION}

The DOE has developed a first-of-a-kind transportation system that consists of a total transport package, including a Nuclear Regulatory Commission (NRC) approved Type "B" container, a lightweight tractor, a custum designed trailer, specially-trained drivers, and a shipment tracking system. In the development effort the DOE has been exceptionally sensitive and responsive to public concerns and the need for safety in the transport of TRU waste to the WIPP site. The transport system meets or exceeds all existing requirements and, in the interest of public safety, incorporates all possible precautionary measures.

THE APPROACH

To prevent the need for special permits, the DOE started with a from-the-ground-up approach and developed an integrated total "transportation system" (container, tractor, trailer, drivers, and tracking system) with a weight limit of 80,000 pounds. The container was designed to maximize capacity and required a custom designed and field-tested trailer. Total weight constraints also required a lightweight custom-built tractor (see Figure 1).

In addition to the transport package, the DOE analyzed all existing requirements and public concerns in the development of its transporiation system. As a development and operating philosophy, safety and security of the shipments took priority over cost and schedule. The product is not ime sensitive in arriving at its destination. Driver compensation is b. miles completed and on hourly rates when not driving. By specific $2 s_{i}$, there is no driver incentive to drive in other than a safe mannar.

\section{TRUPACT - II}

The Transuranic Package Transporter (TRUPACT-II) is a light cylinder with a flat bottom and domed top. The TRUPACT-II package consists of an inner sealed, nonvented, stainless steel containment vessel inside another sealed, 
nonvented, stainless steel containment vessel. Each containment vessel is capable of withstanding 50 pounds of pressure per square inch (psig). The inner containment vessel cavity is approximately six feet in diameter and six feet tal1, with a capacity of fourteen 55-gallon drums. The vessels have removable lids held in place by lock rings and retainers. The outer containment vessel is surrounded by approximately ten inches of polyurethane foam that acts both as a thermal insulator and an energy-absorbing cushion. On the outside of the foam is a stainless steel shell that acts as a protective structure as well as an impact limiter. This sandwich-like method of construction increases the package strength and safety to withstand postulated accidents associated with transport.

As part of the certification process, the TRUPACT-II was subjected to 30 -foot drop tests onto a flat, unyielding surface so that the package's weakest point was struck. This testing included 40 -inch free drops onto a six-inch steel rod, striking the package at its most vulnerable spot, and exposure of the entire package to 1475 degrees for 30 minutes (see Figure 2). Upon completion of these tests, the package was tested to ensure that it was "leak tight" (i.e., it could not leak more than one cubic inch of air in a four year period). When the TRUPACT-II container was subjected to the 30 -foot drop test, instrumentation showed that it experienced " $g$ " forces several times beyond those which would be expected in a vehicular accident.

\section{TRACTOR}

To maximize safety and driver comfort, tractor characteristics and capabilities were studied and a unique lightweight tractor was specially tailored as part of the transportation package. A weight limit of 18,000 pounds was established for a conventional sleeper-type tractor. Actual weight, including fuel, spare tire, tire chains, and drivers is 17,960 pounds. Tractors are dedicated to WIPP shipments only, and are subject to strict inspection and maintenance requirements. By contract, the carrier cannot exceed a two percent downtime rate, and the carrier is required to have an eight-hour enroute tractor replacement capability. All vehicles will be 
inspected to the Commercial Motor Vehicle Alliance standard criteria prior to being dispatched from the maintenance facility to make a TRU waste shipment. Enroute inspection of the tractor, trailer, and container tie-downs is required every two hours or 100 miles. These inspections, coupled with pretrip, post-trip, and potential port-of-entry and weigh scale inspections incurred enroute, equate to 74 possible inspections on a round-trip from the WIPP to the Hanford, Washington site.

To ensure driver adherence to established speed 1 imits, the tractor speedometers have been calibrated; the cruise control cannot be set to exceed $63 \mathrm{MPH}$, and at $65 \mathrm{MPH}$ the fuel pump for the engine ceases to function. Also installed in the vehicle is a "Tripmaster" on-board trip recording computer. Every second of vehicle operation is monitored and recorded.

\section{DRIVERS}

Like the tractors, drivers are dedicated to WIPP shipments only. Shipments are driven by veteran drivers who have completed extensive screening and training prior to being deemed qualified for transporting TRU waste shipments. In selecting a contract carrier, the DOE reviewed existing Department of Transportation (DOT) driver requirements for the transport of radioactive material and chose to exceed them. In the final carrier selection process, the DOE selected a carrier whose driver requirements exceeded both DOT and DOE requirements.

TRU waste drivers must 1 ) be at least 25 years of age; 2) have at least 100,000 miles experience with tractor trailers; 3 ) have two years of uninterrupted experience within the last five years as a tractor-trailer driver; 4) have no moving violations or chargeable accidents in the past three years; 5) be U.S. citizens; 6) submit to substance abuse testing in accordance with DOT guidelines; 7 ) pass a road test; and 8 ) undergo a driver profile examination. The carrier requires drivers to undergo pre-employment, periodic, reasonable cause, and post-accident drug testing. 
Drivers who meet these qualifications receive further training that is provided by the DOE's Transportation Safeguards Training Center. This training utilizes the specific transport vehicle that is "loaded" to its maximum anticipated weight. Drivers are trained on mountainous, flat, rural, city, and interstate routes both at night and during the day. Training is also provided for encountering sabotage, protestors, adverse weather conditions, emergency braking, rollover prevention, and the use of radiation detection instruments. Each tractor will carry properly-calibrated radiation detection instruments for driver use or use by state/local officials. After successful completion of this course, drivers undergo an annual recertification. Drivers are subject to severe penalties for safety violations.

Driver penalties include the following:

- Deviation from route

- First time - Written warning and two weeks leave without pay

- Second time - Termination

- Failure to maintain adequate records

- Same as above

- Failure to maintain constant surveillance

- Termination

- Chargeable accident

- Termination

- Moving violation

- Termination 
TRAILER

In the search for the safest trailer, air-ride and spring-ride trailers in tandem and split axle configurations were reviewed, built, and tested to determine the optimum design. Safety, stability, weight, and durability were prime considerations in selection of the air-ride, split-axle, lightweight trailer fleet model.

\section{SHIPMENT MONITORING}

A unique shipment monitoring capability is accomplished by a satellite-based tracking system referred to as TRANSCOM. Via a personal computer and modem, the system provides the WIPP site, the Oak Ridge National Laboratories TRANSCOM Control Center (TCC), shippers, states, and Indian tribes with the ability to monitor the location and status of all WIPP shipments twenty-four hours per day. The WIPP site, TCC, and shippers also have a two-way satellite communication capability, as well as mobile phone communication with the shipments. In addition, all users of the TRANSCOM system have access to emergency information, advance shipment schedules, and a bill of lading for each shipment.

\section{WEATHER}

To further ensure safety, shipment monitors at the WIPP site also keep abreast of enroute weather conditions via "The Weather Channel" and a commercial PC-based weather system, "KAVOURAS," which provides hourly updates of weather along TRU waste routes. Information available includes 1) route conditions (citing visibility, rain, sleet, snow, etc.); 2) snow depth; 3) wind direction; and 4) wind velocity. Additionally, the monitor has access to the drivers, state and local law enforcement agencies, and the shipping site traffic managers in order to make a rational decision regarding shipments that may be affected by inclement weather (see Figure 3). States are independently developing their own procedures to notify the WIPP of impending road closures or sudden changes in the weather. 


\section{SAFE PARKING}

Should the need arise for a safe temporary parking area, the DOE has entered into an agreement with the Department of Defense (DOD) to allow temporary parking of its TRU waste shipments at military installations along the TRU waste routes, if the situation merits. Exercises of this agreement have been conducted along the TRU waste routes as part of the demonstration runs cited below.

\section{DEMONSTRATION RUNS}

To ensure transportation readiness, "Demo Runs" are being conducted to prospective TRU waste generator sites to check out required procedures. Generator sites gain experience loading the TRUPACT-II containers with "waste" and preparing the accompanying paperwork. Through these exercises, states are able to monitor the progress of "shipments"; "accident" scenarios are conducted; "waste" is unloaded at the WIPP site, emplaced underground, and retrieved. Unannounced tractor replacement exercises have been conducted successfully in as little as three and a half hours. Drivers have been discretely directed to deviate from the prescribed route, with the deviation detected in short order by those monitoring the shipments' progress. As each new generator site prepares to make TRU waste shipments, these exercises will be conducted to establish confidence in all aspects of the transportation system.

\section{SUMMARY}

Components of the system that contribute to safety and efficiency are as follows:

- Maximizing payload and reducing shipments

- Exceptionally strict maintenance requirements for tractors and trailers 
- Frequent vehicle inspections

- Use of highly skilled and trained drivers

- Constant shipment surveillance

- Twenty-four hour per day satellite-based shipment tracking and communication capability

- Mobile telephone unit

- Continuous monitoring of the weather along the routes

- Use of DOD safe parking areas

- Strict adherence to prescribed routes and speed limits

- Continual exercise and refinement of transportation procedures in the interest of safety and efficiency

RESUL.TS

The DOE has developed a radioactive material transport package and systen for the WIPP shipments that maximizes safety and efficiency while addressing public concerns. In June of 1989 the National Academy of Sciences concluded that "The system proposed for transportation of TRU waste to WIPP is safer than that employed for any other hazardous material in the United States today and will reduce risk to very low levels." 


\section{REFERENCES}

National Academy of Sciences, Review Comments on DOE Document DOE/WIPP 89-011: Draft Plan for the Waste Isolation Pilot Plant Test Phase: Performance Assessment and Operations Demonstration, June 19, 1989.

00316 


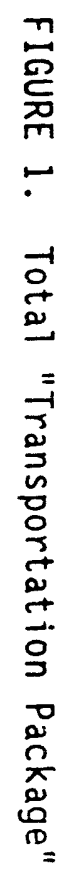

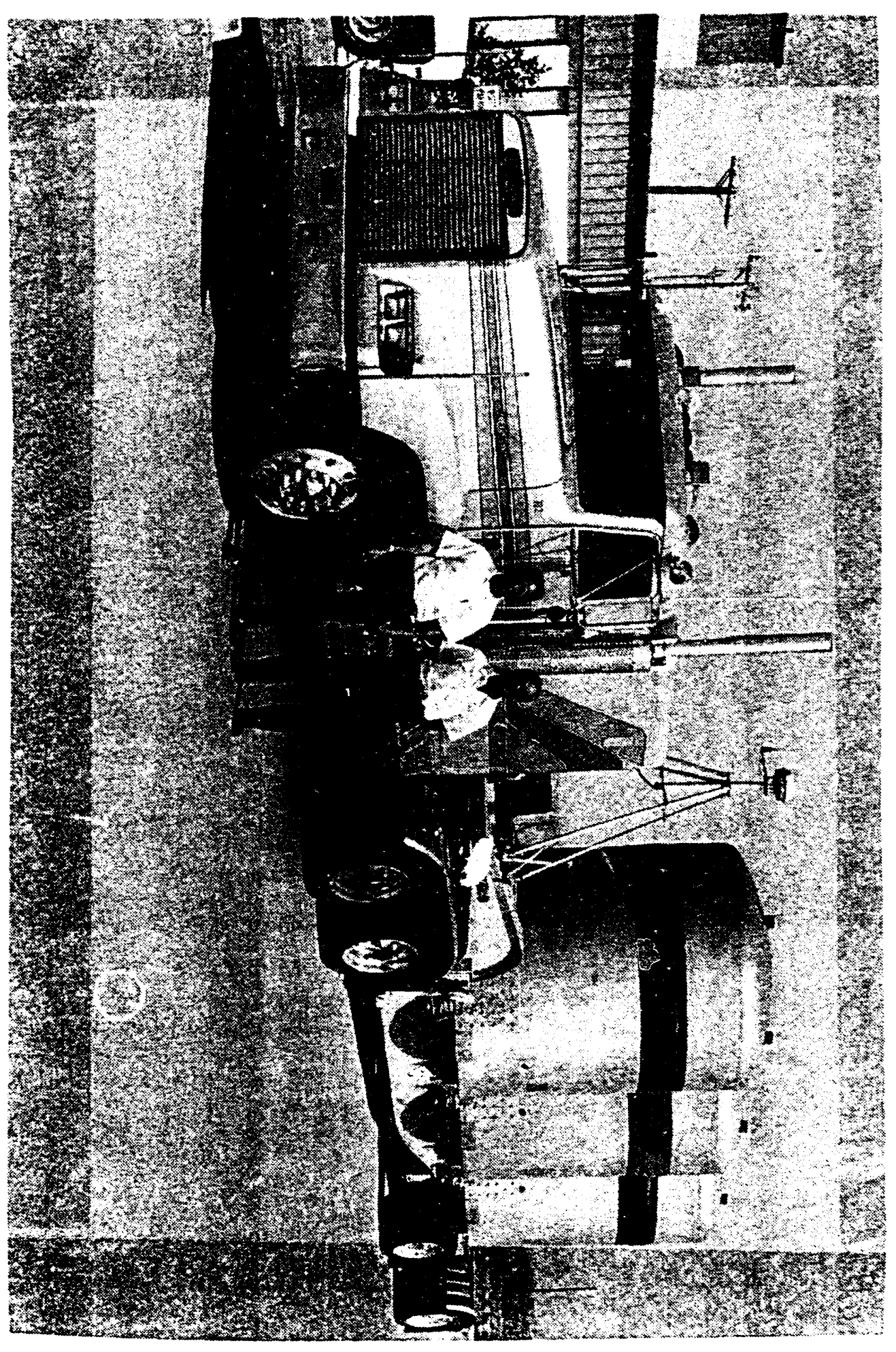




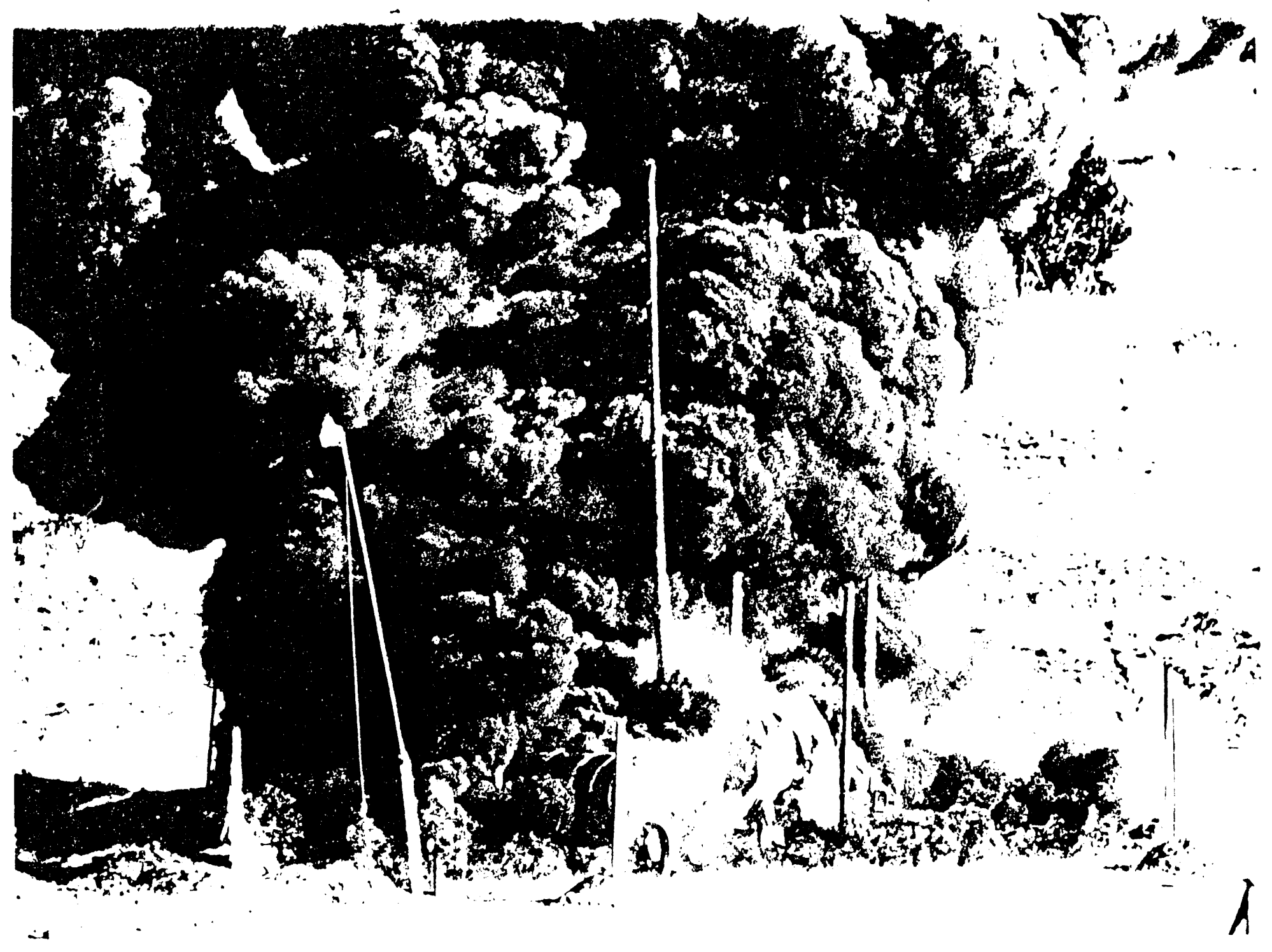

FIGURE 2. TRUPACT-II Burn Test 


\begin{tabular}{|c|c|c|c|c|c|c|c|c|c|}
\hline CITY & SKY & $V I S$ & WEA & TEMP & DEW & HUW & WIND & GUST & EAFI \\
\hline--------- & $---m-m$ & $-\cdots$ & $\ldots-\cdots$ & $\cdots--$ & $-\cdots$ & $-\cdots$ & & $-\cdots-$ & $\ldots-\cdots$ \\
\hline PASCO & P.CLEY & 10 & & 64 & 60 & 87 & CAALIM & $|v|$ & 2978 \\
\hline PENOLETON & CLOUOY & 15 & & 60 & $4 B$ & 64 & $E 03$ & NONE & 2999 \\
\hline BAKER & CLLUUOY & 15 & & 55 & 52 & 90 & 5003 & NONE & 3004 \\
\hline ONTARLO & $m$ & $M$ & & $M$ & $M$ & $M$ & $|M|$ & $M$ & $m$ \\
\hline BOISE & CLLOUOY & 25 & & 59 & 50 & 90 & $\operatorname{SWIO}$ & NOHE & 2995 \\
\hline TWIN FALLS & $M . C L O Y$ & 25 & & 61 & 50 & 67 & CALLIY & $|M|$ & 3003 \\
\hline ILAHO FALLS & M.CLDY & 20 & & 57 & 53 & 86 & $N E \perp 0$ & NONE & 3012 \\
\hline DOCATELLO & M.CLLOY & 50 & & 67 & 48 & 50 & $N W \perp \perp$ & NONE & 3004 \\
\hline OUDEN & M.CLDY & 50 & & 73 & 49 & 43 & 514 & NONE & 3002 \\
\hline EVANSTON & $M \mid$ & $M_{i}$ & & $M$ & $M$ & $M$ & $M$ & $M$ & $M$ \\
\hline ROCK SPRINGS & P.CLDY & 50 & & 67 & 41 & 39 & $S E \perp 4$ & NONE & 3024 \\
\hline RAWLINS & M.CLDY & 60 & & 70 & 37 & 32 & $w 13$ & NONE & 3027 \\
\hline LARAMIE & CLEAR & 50 & & ob & 40 & 48 & $\operatorname{SEL1}$ & NONE & $30 \geq 8$ \\
\hline CHEYENINE & P.CLOY & 60 & & 57 & 53 & 61 & 510 & NOINE & 3027 \\
\hline DENVER & F. CLOY & 50 & & 70 & 50 & 49 & $S W 10$ & NONE & 3020 \\
\hline COLORAOO SPRS & P.CLOY & 65 & & 67 & 52 & 59 & SEO9 & NONE & 3027 \\
\hline PUEELO & M.CLEYY & 80 & & 70 & 56 & 61 & $5 w 04$ & NOHE & $30=2$ \\
\hline TRINIDAD & MI CLOY & 60 & & 73 & 49 & 43 & $\operatorname{sw11}$ & NOME & 3030 \\
\hline LAS VEGAS & M.CLOY & 25 & & 62 & 52 & 70 & $N E \perp \Xi$ & NONE & 5030 \\
\hline ROSWELL & $M \mid$ MLDY & 35 & & 78 & 64 & $0 ?$ & NEOG & NONE & 3010 \\
\hline CARLSBAL & P. CLDY & 50 & & 81 & ¿6 & 60 & SEOS & NONE & 3014 \\
\hline
\end{tabular}

FIGURE 3. TRU Waste Route Weather 


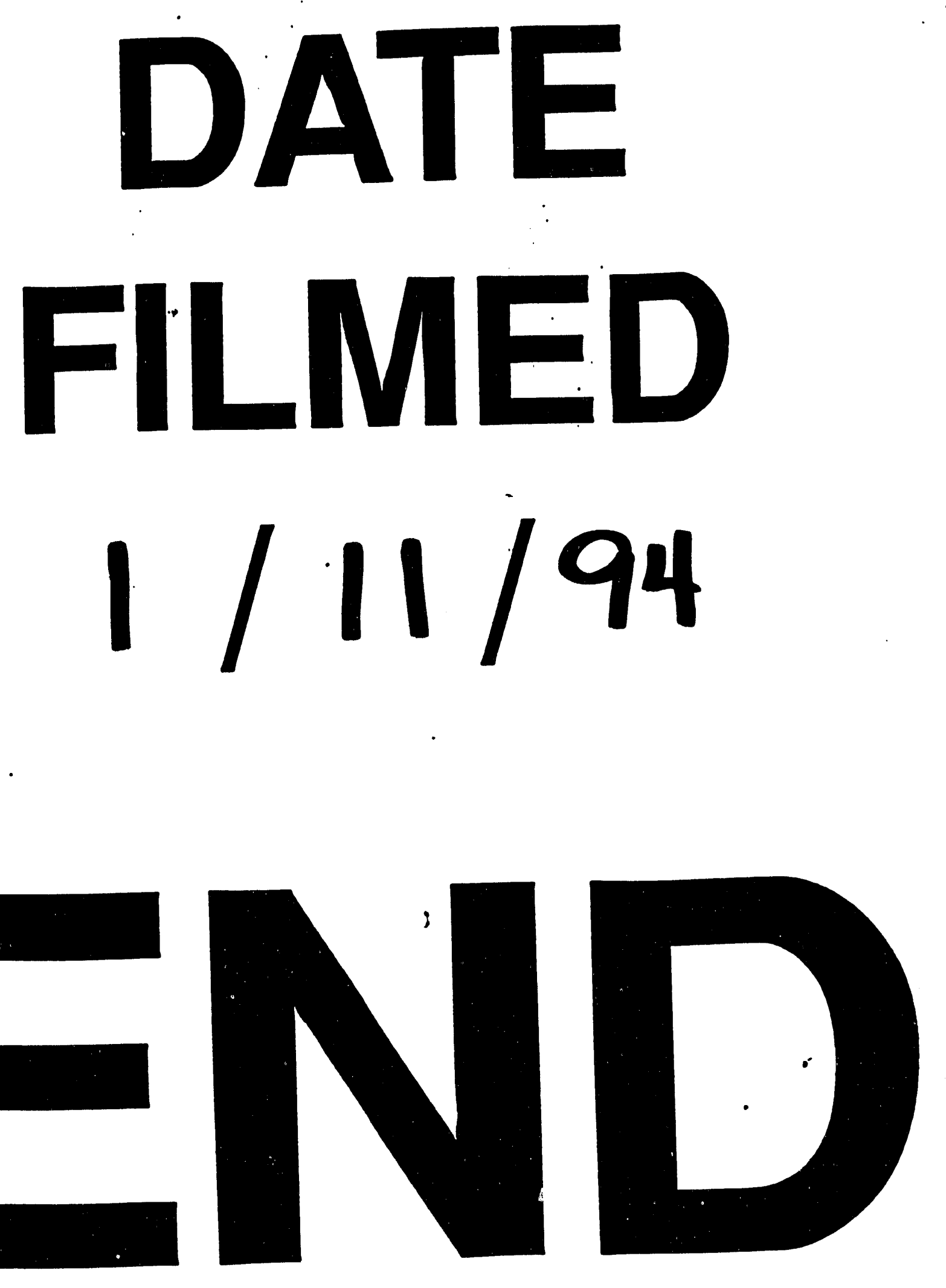




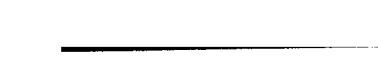

